\title{
Cycling of winter forage nutrients under integrated crop-livestock systems
}

\author{
Andressa Perini Vengen ${ }^{1}$, Bruna Thaina Bartzen ${ }^{1}$, Eloisa Mattei ${ }^{1}$, Carlos Augusto Rocha de \\ Moraes Rego ${ }^{1}$, Jeferson Tiago Piano ${ }^{1}$, Paulo Sergio Rabello de Oliveira ${ }^{1}$
}

\begin{abstract}
${ }^{1}$ Universidade Estadual do Oeste do Paraná, Campus Marechal Cândido Rondon, Marechal Cândido Rondon, Paraná, Brasil. E-mail: andressaperini@hotmail.com, bruna_bartzen@hotmail.com, eloisa-mattei@hotmail.com, cassielcarlos@hotmail.com, jefersontpiano@hotmail.com, rabello.oliveira@hotmail.com
\end{abstract}

Received: 02/05/2020; Accepted: 01/10/2020.

\begin{abstract}
This study aimed to evaluate the decomposition and release of nutrients from the remaining straw of two annual forage species conducted in an integrated crop-livestock system (ICLS). The experimental design used was randomized blocks, in split plots, with three replicates. The managements were allocated in the plots $\left(52 \mathrm{~m}^{2}\right)$ : without grazing, one grazing, and two grazings. Subplots were defined by material collection times after the forage's desiccation $(0,30,60,90$, and 120 days after desiccation). Dry matter yield, amounts of carbon, nitrogen, phosphorus, and potassium, and half-life time were evaluated. Oat cultivar IPR Esmeralda had the highest initial dry matter yield $\left(6,099 \mathrm{~kg} \mathrm{ha}^{-1}\right)$ when not grazed, while triticale cultivar IPR 111 showed the highest average values when subjected to grazing $\left(8,088 \mathrm{~kg} \mathrm{ha}^{-1}\right)$. The amounts of $\mathrm{N}, \mathrm{P}$, and $\mathrm{K}$ released from the remaining dry matter, regardless of the management adopted, decreased over time. Potassium was the nutrient that presented the most accelerated release, with an average half-life of 14 days. When subjected to grazing, triticale is more efficient in nutrient cycling, providing 197, 38, and $231 \mathrm{~kg} \mathrm{ha}^{-1}$ of $\mathrm{N}, \mathrm{P}$, and $\mathrm{K}$, respectively, with a half-life time of 10, 37, and 25 days, respectively. Forage species can improve the cycling of nutrients and make them available to crops in succession in the ICLS.
\end{abstract}

Keywords: management systems, crop succession, plant residues.

\section{Ciclagem de nutrientes de forrageiras invernais sob sistema de integração lavoura-pecuária}

\section{RESUMO}

Este estudo teve como objetivo avaliar a decomposição e liberação de nutrientes da palhada remanescente de duas espécies forrageiras anuais conduzidas em sistema de integração lavoura-pecuária (ILP). O delineamento experimental utilizado foi o de blocos ao acaso, em parcelas subdividas, com três repetições. Nas parcelas $\left(52 \mathrm{~m}^{2}\right)$ foram alocados os manejos: sem pastejo, um pastejo e dois pastejos. As subparcelas foram constituídas pelas épocas de coleta do material, após a dessecação das forrageiras $(0,30,60$, 90, e 120 dias após a dessecação). Determinouse a produtividade da matéria seca, quantidades de carbono, nitrogênio, fósforo e potássio e o tempo de meia-vida. A aveia IPR Esmeralda apresentou a maior produtividade de matéria seca inicial $\left(6.099 \mathrm{~kg} \mathrm{ha}^{-1}\right)$ quando não pastejada, enquanto o Triticale IPR 111 obteve as maiores médias quando submetido a um pastejo ( $\left.8.088 \mathrm{~kg} \mathrm{ha}^{-1}\right)$. As quantidades de N, P e K liberadas da matéria seca remanescente, independente do manejo adotado, apresentaram decréscimo ao longo do tempo. O potássio foi o nutriente que apresentou liberação mais acelerada, com tempo de meia vida médio de 14 dias. O Triticale IPR 111, quando submetido a um pastejo, é mais eficiente na ciclagem de nutrientes, disponibilizando 197, 38 e $231 \mathrm{~kg} \mathrm{ha}^{-1}$ de N, P e K, com tempo de meia vida de 10, 37 e 25 dias, respectivamente. No ILP as espécies forrageiras são capazes de melhorar a ciclagem dos nutrientes e disponibilizálos para as culturas em sucessão.

Palavras-chave: sistemas de manejo, sucessão de culturas, resíduos vegetais. 


\section{Introduction}

The integrated crop-livestock system (ICLS) has been widespread in recent years due to its benefits to agricultural activity, with the possibility of economic and environmental gains (Santos et al., 2014). In the Brazilian subtropics, this system is characterized by being associated with areas under no-tillage that, during the winter, are cultivated with annual forage (in monoculture or intercropped) and, in the summer, they are occupied by grain-producing crops (Moraes et al., 2014).

One of the important characteristics of the ICLS is the nutrients cycling by forage species and subsequent availability for crops in succession (Dubeux Jr. et al., 2014). Through the decomposition and release of their nutrients, forages contribute to the rationalization of inputs usage, reducing the amount of employed fertilizers over time and decreasing the production cost and environmental imbalance (Santos et al., 2014).

The decomposition and nutrient release are governed by several factors, such as climatic conditions, material quality, soil type, fertility (Anghinoni et al., 2011; Marcelo et al., 2012; Santos et al., 2014), and the presence of animals in the system. These last ones are responsible for modifying the flows between the compartments by ingesting nutrients via forage consumption, digestion, and subsequent return to the system in the form of waste (Anghinoni et al., 2011). For a plant species to be effective in nutrient cycling, there must be synchrony between the nutrient released by the cover plant residue and the demand for the crop of commercial interest, grown in succession (Hentz et al., 2014).

In the western region of Paraná, white oat is used in the winter season as an option for grazing dairy cattle and soil covering with the nutrient release for the crop in succession. It is also indicated for the dual purpose, grain production, or grazing, as it presents good dry matter production, good regrowth capacity, tillering, and good leaf/stem ratio (Silva et al., 2006; Meinerz et al., 2011).

Triticale is also an option for integrated croplivestock, used for grazing and soil covering. It is a rustic plant, with great growth capacity, even under adverse conditions, such as low fertility areas and susceptible to frost (Dumbrava et al., 2014).

Studies aiming to evaluate management and forage species' behavior and interference on the decomposition and nutrient release in integrated crop-livestock systems are of fundamental importance. Thus, this study aimed to evaluate the decomposition and nutrient release from the remaining straw of two annual forage species conducted under an integrated crop-livestock system.

\section{Material and Methods}

This experiment was carried out under field conditions, at the Experimental Farm "Professor Antônio Carlos dos Santos Pessoa", belonging to the Western Paraná State University - UNIOESTE, Campus of Marechal Cândido Rondon, located in the Western Paraná, latitude $24^{\circ} 31^{\prime} 58^{\prime \prime} \mathrm{S}$ and longitude $54^{\circ} 01^{\prime} 10^{\prime \prime} \mathrm{W}$, with an approximate altitude of $400 \mathrm{~m}$. The soil is classified as a very clayey Eutrophic Red Latosol (Santos et al., 2018). According to the Köppen classification, the region's climate is a Cfa-type, humid subtropical climate, with average temperatures varying between $17^{\circ} \mathrm{C}$ and 19 ${ }^{\circ} \mathrm{C}$ and an average annual rainfall of $1,500 \mathrm{~mm}$ (Alvares et al., 2013). The climatic data during the experimental period (Figure 1) were obtained from the Automatic Climatological Station of the Nucleus of Experimental Stations at UNIOESTE, located near the experimental area.

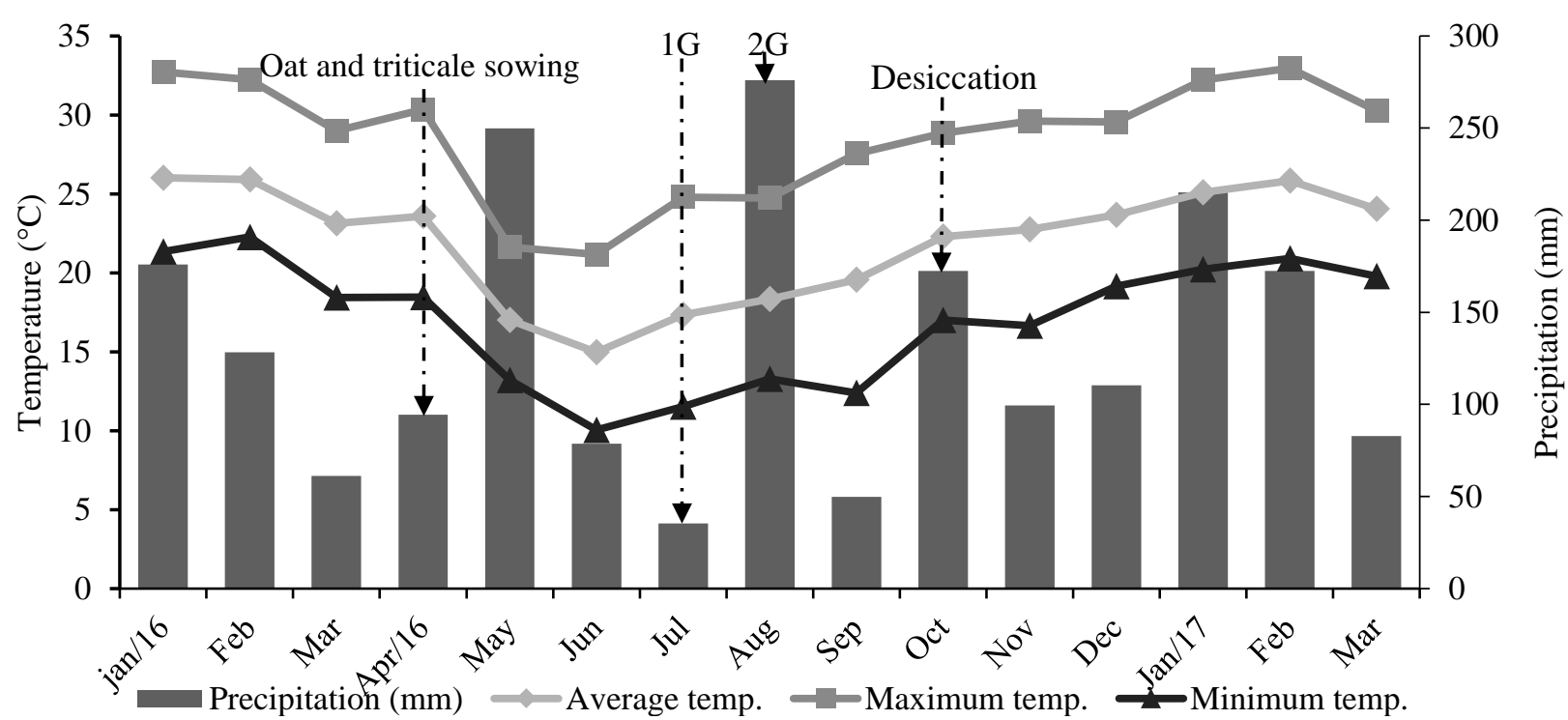

Figure 1. Monthly averages of maximum, minimum, and mean temperatures, and accumulated rainfall during 2016 and 2017 , during the experimental period. 1P and 2P: first and second grazing of winter forage, respectively. Source: Automatic Climatological Station located at the Nucleus of Experimental Stations of UNIOESTE, Marechal Cândido Rondon - PR. 
The area had been managed for five years under the ICLS, with consolidated no-till. During the past two years, soybeans were cultivated in the summer and forage species (Urochloa brizantha and Avena sativa) single or intercropped for grazing dairy cattle in winter. Before implementing the experiment, soil collection was carried out to identify the need for liming and/or fertilization (CQFSRS/SC, 2004). The chemical and granulometric properties are described in Table 1.

A randomized block experimental design in subdivided plots with three replications was used. The managements were allocated in the plots $\left(52 \mathrm{~m}^{2}\right)$ : without grazing, one grazing, and two grazings, with a residue height of $15 \mathrm{~cm}$. The subplots were defined by collecting the materials after the forage's desiccation $(0,30,60,90$, and 120 days after desiccation (DAD)).

Before sowing forage crops, with 30 days in advance, the area was desiccated using glyphosate isopropylamine salt, at the doses of $4.0 \mathrm{~L} \mathrm{ha}^{-1}$ and $0.5 \mathrm{~L} \mathrm{ha}^{-1}$ of a commercial product containing $480 \mathrm{~g} \mathrm{~L}^{-1}$ and $240 \mathrm{~g} \mathrm{~L}^{-1}$ of the active ingredient, respectively.

The sowing of white oat, cultivar IPR Esmeralda, and triticale, cultivar IPR 111, was carried out in the autumn/winter period, on April 16, 2016, in a mechanized and direct way over soybean straw, using 60 $\mathrm{kg} \mathrm{ha}^{-1}$ and $140 \mathrm{~kg} \mathrm{ha}^{-1}$ of seeds of oat and triticale, respectively, with a row spacing of $0.17 \mathrm{~m}$. The fertilization at sowing was carried out using $250 \mathrm{~kg} \mathrm{ha}^{-1}$ of the NPK formulation 10-15-15 (N, $\mathrm{P}_{2} \mathrm{O}_{5}$, and $\left.\mathrm{K}_{2} \mathrm{O}\right)$. For the topdressing fertilization, $120 \mathrm{~kg} \mathrm{ha}^{-1}$ of $\mathrm{N}$ in the form of urea was applied.

The topdressing fertilization was carried out manually, in the plots where there was no grazing and with only one grazing, divided into two applications of $60 \mathrm{~kg} \mathrm{ha}^{-1}$. The first application was performed at the beginning of tillering and the second application, after the first grazing, at 30 and 83 days after sowing. In the plots managed with two pastures, the parceling was carried out three times $\left(40 \mathrm{~kg} \mathrm{ha}^{-1}\right)$, with the last application being made after the second grazing, at 119 days after sowing. There was no need to apply herbicides, insecticides, and/or fungicides during the oat and triticale cycle.

Grazings were started when the plants were between 0.25-0.35 m tall, about 80 days after emergence. Twelve Holstein animals were used, in the lactation phase, with an average weight of $600 \mathrm{~kg}$. The animals remained for about four hours daily (two in the morning and two in the afternoon) or until the stubble height reached between 0.15 and $0.20 \mathrm{~m}$, avoiding damage to the apical meristem. With the animals' departure, the area remained at rest for 30 days, after which the second grazing was carried out, like the first.

The forages were desiccated before the implantation of the summer crop, about 40 days after the second grazing, using glyphosate isopropylamine salt + clethodim at the dose of $3.0 \mathrm{~L} \mathrm{ha}^{-1}$ and $0.40 \mathrm{~L} \mathrm{ha}^{-1}$ of a commercial product containing $480 \mathrm{~g} \mathrm{~L}^{-1}$ and $240 \mathrm{~g} \mathrm{~L}^{-1}$ of the active ingredient, respectively.

Soybean sowing was carried out in a direct sowing system on straw in October 2016, about 30 days after desiccation, using the cultivar NIDERA 5909 RR, 13 seeds per meter, and row spacing of $50 \mathrm{~cm}$. The seeds were treated with fungicides Carbendazim + Thiram and insecticide Fipronil. The sowing fertilization was $310 \mathrm{~kg}$ $\mathrm{ha}^{-1}$ of NPK formulation 02-20-18 ( $\left.\mathrm{N}, \mathrm{P}_{2} \mathrm{O}_{5}, \mathrm{~K}_{2} \mathrm{O}\right)$. Phytosanitary treatments were carried out according to the crop's needs.

The evaluation of straw decomposition and nutrient release started with the forage's desiccation. Collections were performed at $0,30,60,90$, and 120 days after desiccation. Vegetable materials were collected with the aid of a metal square, with a known area $\left(0.25 \mathrm{~m}^{2}\right)$, randomly launched in each plot. These samples were packed in paper bags and sent to the forced circulation oven at about $65{ }^{\circ} \mathrm{C}$ until the samples' weight became constant (approximately $48 \mathrm{~h}$ ). After drying, the samples were weighed again to determine the dry matter, and the values converted to $\mathrm{kg} \mathrm{ha}^{-1}$. Subsequently, the material was sent to the Soil Fertility and Plant Nutrition Laboratory and crushed in a Willey Mill to determine the amounts of $\mathrm{C}, \mathrm{N}, \mathrm{P}$, and $\mathrm{K}$ contained in each sample.

Table 1. Soil chemical and granulometric properties of the soil, in the $0-10$ and $10-20 \mathrm{~cm}$ layers, before the winter crops sowing, in 2016.

\begin{tabular}{|c|c|c|c|c|c|c|c|c|c|c|c|}
\hline Layer & $\mathrm{P}$ & OM & $\mathrm{pH}$ & $\mathrm{H}+\mathrm{Al}$ & $\mathrm{Al}^{3+}$ & $\mathrm{K}^{+}$ & $\mathrm{Ca}^{2+}$ & $\mathrm{Mg}^{2+}$ & SB & CEC & $\mathrm{V}$ \\
\hline $\mathrm{cm}$ & $\mathrm{mg} \mathrm{dm}^{-3}$ & $\mathrm{~g} \mathrm{dm}^{-3}$ & $\mathrm{CaCl}_{2}$ & \multicolumn{7}{|c|}{$\mathrm{cmol}_{\mathrm{c}} \mathrm{dm}^{-3}$} & $\%$ \\
\hline $0-10$ & 22.8 & 39.64 & 4.7 & 6.6 & 0.0 & 0.3 & 3.3 & 1.4 & 4.9 & 9.5 & 51.6 \\
\hline $10-20$ & 30.3 & 23.24 & 4.6 & 6.8 & 0.3 & 0.1 & 3.3 & 1.4 & 4.9 & 10.3 & 47.4 \\
\hline Layer & & \multicolumn{3}{|c|}{ Clay } & \multicolumn{4}{|c|}{ Silt } & \multicolumn{3}{|c|}{ Sand } \\
\hline $\mathrm{cm}$ & \multicolumn{11}{|c|}{--------------------------------------------------- g kg } \\
\hline $0-10$ & \multirow{2}{*}{\multicolumn{3}{|c|}{681}} & \multicolumn{3}{|c|}{266} & \multicolumn{5}{|c|}{52} \\
\hline $10-20$ & & & & \multicolumn{3}{|c|}{199} & \multicolumn{5}{|c|}{49} \\
\hline
\end{tabular}

$\mathrm{P}$ and $\mathrm{K}$ - MEHLICH-1 Extractor; $\mathrm{Al}, \mathrm{Ca}$, and $\mathrm{Mg}-\mathrm{KCl}\left(1 \mathrm{~mol} \mathrm{~L}^{-1}\right)$ Extractor; $\mathrm{H}+\mathrm{Al}-\mathrm{pH} \mathrm{SMP}(7,5)$. 
Carbon was obtained from the organic matter's determination in a muffle, as described by Silva and Queiroz (2006). These nutrients assessment was carried out from sulfuric digestion. In the obtained extracts, the $\mathrm{K}$ content was determined by flame photometry and the $\mathrm{N}$ content by distillation in a Kjeldahl semi-micro system, as described by Tedesco et al. (1995), while $\mathrm{P}$ content was determined by UV-VIS spectrophotometry, according to Braga and Defelipo (1974).

The straw decomposition and nutrient release rates from the remaining dry matter were determined from the results obtained using the simple negative exponential mathematical model, $\mathrm{X}=\mathrm{Xo.} \mathrm{e}^{\mathrm{kt}}$ (Thomas and Asakawa, 1993). In this model, $X$ is the amount of dry matter or nutrients remaining; $t$ is the time in days; Xo refers to the amount of dry matter at the beginning of the decomposition, and $\mathrm{k}$ is the decomposition constant. The half-life time $\left(\mathrm{T}^{1} 12=0.693 / \mathrm{k}\right)$ was calculated from the $\mathrm{k}$ value (Paul and Clark, 1989), representing the period required for $50 \%$ of the waste to decompose or for the half time necessary for the nutrients in the waste be released.

The data were submitted to the analysis of variance using the F Test $(\mathrm{p}<0.05)$, using the SISVAR statistical program (Ferreira, 2011). When significant, a mathematical model was chosen. The species' study was carried out separately since the triple interaction results (management $\mathrm{x}$ forage $\mathrm{x}$ time) did not allow coherent conclusions.

The model type was chosen based on the significance of the equation parameters and the determination coefficient $\left(\mathrm{R}^{2}\right)$, which indicates the degree of association between the observed values and the adjusted model. The equations were obtained using the SigmaPlot ${ }^{\circledR} 13.0$ Software.

\section{Results and Discussion}

The interaction between management factors (no grazing, one grazing, and two grazings) and the decomposition time after desiccation $(0,30,60,90$, and 120 DAD) for white oat (cv. IPR Esmeralda) and triticale (cv. IPR 111), was significant for all the studied variables: dry matter, nitrogen, phosphorus, potassium, and carbon remaining.

The largest accumulation of white oat dry matter was found in areas with no grazing of the animals, with an initial quantity of $6,099 \mathrm{~kg} \mathrm{ha}^{-1}$. On the other hand, the lowest accumulation occurred in plots grazed twice, with average values of $2,699 \mathrm{~kg} \mathrm{ha}^{-1}$ and a reduction of approximately $44 \%$ in the amount of accumulated biomass (Figure 2A).

The triticale's dry matter behavior was very similar in areas without grazing or with one grazing, with yields of $7,962 \mathrm{~kg} \mathrm{ha}^{-1}$ and $8088 \mathrm{~kg} \mathrm{ha}^{-1}$, respectively. The area subjected to two grazings resulted in lower dry matter yield (3,600 kg ha-1), with a reduction of around $60 \%$ compared to the area with one grazing (Figure 2B).

The amount of dry matter of the species found where the grazing frequency was higher was already expected, since the more grazing, the greater the amount of forage consumed and, consequently, the less the residue left on the soil. However, according to Assmann et al. (2008), so that the no-tillage system is not harmed, it is necessary at least $2,000 \mathrm{~kg} \mathrm{ha}^{-1}$ of final residual dry matter, in the case of white oat. Thus, although two pastures promoted a reduction in the amount of final residual material, it was virtually twice the minimum tolerable for the system's continuity.

In general, it can be observed that there was an exponential decrease in the dry matter remaining over time, regardless of the species used and the management adopted (Figure 2). In areas conducted with or without grazing, the decomposition was faster, with a reduction of $77 \%$ and $78 \%$ in the white oat dry matter amount, respectively, at $120 \mathrm{DAD}$. In the areas managed under two grazings, the decomposition was slower, with a reduction of only $37 \%$ in the same period (Figure $2 \mathrm{~A}$ ).

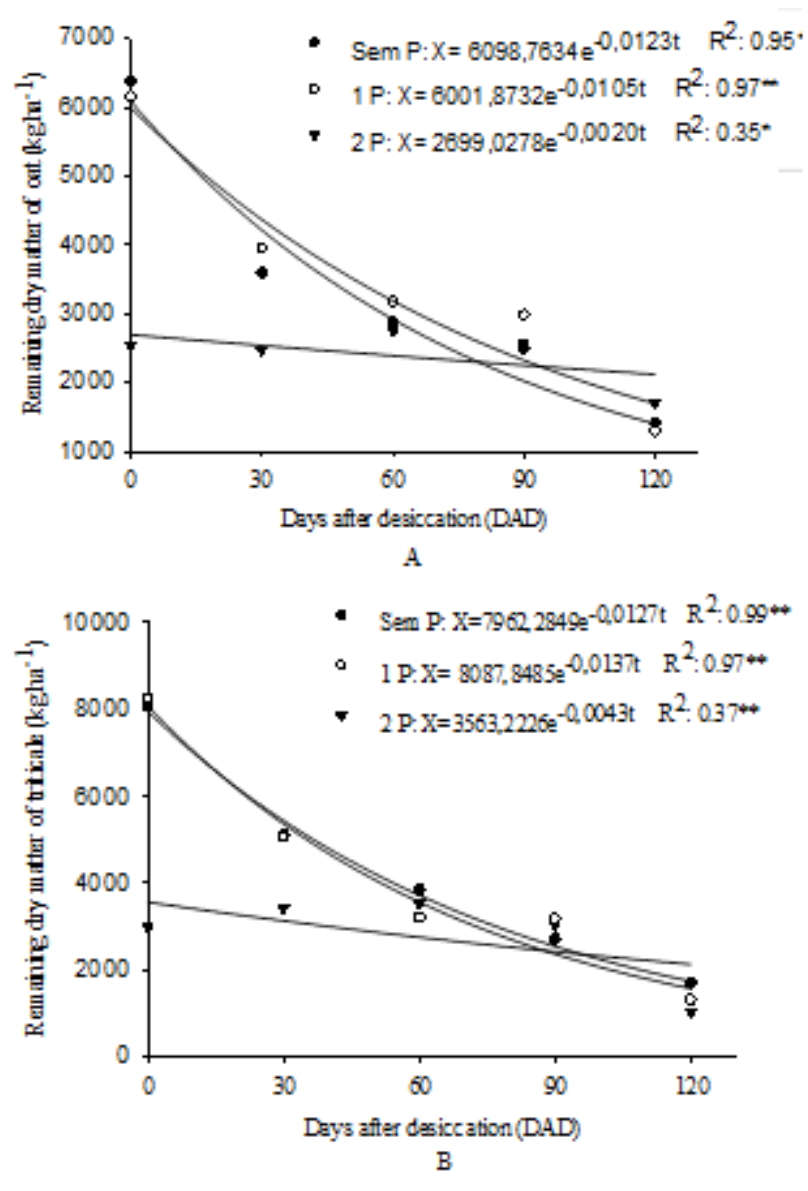

Figure 2. Remaining dry matter of white oat (cv. IPR Esmeralda) (A) and triticale (cv. IPR 111) (B), submitted to management without grazing (WG), one grazing (1G), and two grazings $(2 \mathrm{G})$, conducted in an integrated crop-livestock system. **Significant at $1 \%$ by the F-test; *Significant at $5 \%$ by the F-test. 
Studies conducted by Taffarel et al. (2017) in the western Paraná evaluating the effects of grazing on the agronomic traits and grain yield of some forage plants, they observed that the management with two grazings reduced the dry matter yield of the triticale cv. IPR 111 by approximately $55 \%$, due to the greater export by animals.

The higher decomposition speed in areas not grazed is due to the greater amount of dry matter deposited on the surface, which influences the temperature and humidity of the soil, generating favorable conditions for the survival and growth of the population of decomposing organisms, which increases the speed of residues decomposition present in the soil (Medrado et al., 2011). The same authors reported similar results where animals' presence reduced the crop residues decomposition speed compared to not grazed areas. The result that supports this hypothesis can be verified by observing the half-life time $\left(\mathrm{T}^{1 / 2}\right)$ of the remaining biomass (Tables 2 and 3). For the area of ungrazed white oat, it resulted in a greater accumulation of dry matter, with a half-life time of 56 days, while where there were one and two grazings, the $\mathrm{T}^{1} \frac{1}{2}$ was 66 and 346 days, respectively (Table 2 ).

The $T^{1} \frac{2}{2}$ of the triticale plant biomass ranges according to the management adopted (Table 2). In general, the values found for areas without grazing and with one grazing were close (55 and 51 days, respectively), which is justified by a similar amount of the remaining dry matter. In the area subjected to two grazings, the decomposition of $50 \%$ of the material took a longer time (161 days).

The $T^{1 / 2}$ of plant residues is directly related to the consolidation and maintenance of the no-till system. The choice of species aiming at soil cover and nutrient cycling becomes important in the diversification of agricultural production, with maintenance and protection of the soil-plant system (Calvo et al., 2010).

The material left on the soil surface by forage species is closely related to its chemical, physical, and biological quality and directly affects successive crops. According to Krutzmann et al. (2013), these residues' nature will define the magnitude and rates of nutrient release from forage biomass to crops.

The speed of nutrient release from plant residues can be seen in the figures below (Figure 3). According to Giacomini et al. (2003), this variable will depend on the location and how these nutrients are found in the plant tissue.

In general, the values of $\mathrm{C}, \mathrm{N}, \mathrm{P}$, and $\mathrm{K}$ accumulated in the remaining dry matter, in the managements without grazing and with one grazing, for both white oat and triticale were very close (Figure 3), as well as the halflife time (Tables 2 and 3). This fact can be justified by the similarity in the biomass accumulated in each treatment. The areas with two grazings, which had lower dry matter, also showed less cycling and availability of these nutrients.

The total carbon content showed similar behavior to both species' remaining dry matter (Figure 3A and 3B). However, Mattei et al. (2018) found analogous results evaluating the decomposition and nutrient release from black oat submitted to grazing frequencies. The loss of $\mathrm{C}$ of the residue reported was proportional to the remaining dry matter's mass loss since the microorganisms that colonize vegetable residues use $\mathrm{C}$ as an energy source.

For the oat cultivation, the largest amount of carbon was found in the area without grazing $\left(3,267 \mathrm{~kg} \mathrm{ha}^{-1}\right)$ (Figure $3(\mathrm{~A})$ ), with an estimated $\mathrm{T}^{1} / 2$ of 57 days (Table 2). On the other hand, the lowest levels $\left(1,406 \mathrm{~kg} \mathrm{ha}^{-1}\right)$ were found when managed under two grazings, promoting a reduction of $57 \%$ when comparing the two managements.

When assessing the balance of organic carbon in the soil under an integrated crop-livestock system, Nicoloso et al. (2008) concluded that increasing the grazing frequency in winter pasture reduced $\mathrm{C}$ in the soil. It is estimated the need for annual addition of $4,500 \mathrm{~kg} \mathrm{ha}^{-1}$ of $\mathrm{C}$ to the soil, from the dry matter of plants to maintain the original stocks of $\mathrm{C}$.

In the area with triticale, managed without grazing and with one grazing, $50 \%$ of the dry matter's carbon was available up to 53 and 50 days, respectively (Figure 3B). At 120 days after management, $79 \%$ and $84 \%$ of the initial $\mathrm{C}$ content had already been released. Conversely, in two grazings' management, the half-life time was 169 days (Table 3).

Nitrogen is found in large quantities in the remaining plant material due to its functions in the plants metabolism, including the synthesis of nucleic acids, proteins, hormones, and chlorophyll (Silva and Monteiro, 2007). This essential nutrient was identified, especially in oats managed under one grazing and triticale without grazing, which presented $114 \mathrm{~kg} \mathrm{ha}^{-1}$ and $208 \mathrm{~kg} \mathrm{ha}^{-1}$ of $\mathrm{N}$, respectively (Figure 3B and 3C).

The smallest amount of initial $\mathrm{N}$ was found in the area under two grazings, both with oat and triticale (Figure 3B and $3 \mathrm{C}$ ). This behavior may have occurred because nitrogen is related to the amount of waste stored in the soil (Acosta et al., 2014). Thus, as the oats were grazed twice, there was a reduction in plant material due to the animals' defoliation, which resulted in less remaining dry matter and, proportionally, nitrogen.

Assmann et al. (2014), when investigating the impact of the introduction of grazing in rotations with soy regarding the stocks of $\mathrm{C}$ and $\mathrm{N}$, also observed this reduction in $\mathrm{N}$ content in the grazed area. The authors verified that high grazing intensities decreased $\mathrm{C}$ and $\mathrm{N}$ levels compared to the treatment without grazing. 
When studying the nutrient accumulation in the black oat, forage turnip, common vetch, and fallow with spontaneous vegetation, Wolschick et al. (2016) obtained $92 ; 75 ; 262$ and $28 \mathrm{~kg} \mathrm{ha}^{-1}$ of $\mathrm{N}$, respectively. Therefore, it is noted the triticale $\mathrm{N}$ cycling capacity, being lower only than the common vetch, in this case.

The half-life time of the remaining nitrogen in the plant tissue was 62, 65, and 139 days for oats in the management without grazing, one grazing, and two grazings, respectively. For triticale, the half-life time when grazed once or not grazed was 37 days; however, when grazed twice, $\mathrm{T}^{1 / 2}$ was 114 days. The faster release of $\mathrm{N}$ in materials conducted without grazing and with one grazing may be associated with a greater amount of remaining dry matter (Figures $3 \mathrm{~A}$ and $3 \mathrm{~B}$ ), promoting more suitable conditions for developing microorganisms favoring their availability. By contrast, Mattei et al. (2018) found that observing a higher amount of nitrogen in the areas with two grazings and a higher $\mathrm{T}^{1} / 2$ in the remaining straw without grazing.

Table 2. Parameters of the models adjusted $\left(X=X o \cdot e^{-k t}\right)$ to the remaining dry matter, nitrogen, phosphorus, potassium, and carbon values, half-life time ( $\mathrm{T}^{1 / 2}$ ), and $\mathrm{R}^{2}$ values of the management of white oat (cv. Esmeralda) in an integrated crop-livestock system.

\begin{tabular}{|c|c|c|}
\hline Management & $\mathrm{k}^{(1)}$ & $T^{1 / 2(2)}$ Days \\
\hline \multicolumn{3}{|c|}{ Remaining dry matter } \\
\hline Without grazing & 0.0123 & 56 \\
\hline One grazing & 0.0105 & 66 \\
\hline Two grazings & 0.0020 & 346 \\
\hline \multicolumn{3}{|c|}{ Remaining total carbon } \\
\hline Without grazing & 0.0122 & 57 \\
\hline One grazing & 0.0108 & 64 \\
\hline Two grazings & 0.0024 & 289 \\
\hline \multicolumn{3}{|c|}{ Remaining nitrogen } \\
\hline Without grazing & 0.0112 & 62 \\
\hline One grazing & 0.0106 & 65 \\
\hline Two grazings & 0.0050 & 139 \\
\hline \multicolumn{3}{|c|}{ Remaining phosphorus } \\
\hline Without grazing & 0.0055 & 126 \\
\hline One grazing & 0.0119 & 58 \\
\hline Two grazings & 0.0060 & 112 \\
\hline \multicolumn{3}{|c|}{ Remaining potassium } \\
\hline Without grazing & 0.0948 & 7 \\
\hline One grazing & 0.0986 & 7 \\
\hline Two grazings & 0.0732 & 10 \\
\hline
\end{tabular}

(1) Decomposition constant; ${ }^{(2)}$ Half-life time.

Table 3. Parameters of the models adjusted $\left(X=X o \cdot e^{-k t}\right)$ to the remaining dry matter, nitrogen, phosphorus, potassium, and carbon values, half-life time ( $\mathrm{T}^{1 / 2}$ ), and $\mathrm{R}^{2}$ values of the management of triticale (cv. IPR 111) in an integrated crop-livestock system.

\begin{tabular}{|c|c|c|}
\hline Management & $\mathrm{k}^{(1)}$ & $\mathrm{T}^{1 / 2(2)}$ Days \\
\hline \multicolumn{3}{|c|}{ Remaining dry matter } \\
\hline Without grazing & 0.0127 & 55 \\
\hline One grazing & 0.0137 & 51 \\
\hline Two grazings & 0.0043 & 161 \\
\hline \multicolumn{3}{|c|}{ Remaining total carbon } \\
\hline Without grazing & 0.0130 & 53 \\
\hline One grazing & 0.0138 & 50 \\
\hline Two grazings & 0.0041 & 169 \\
\hline \multicolumn{3}{|c|}{ Remaining nitrogen } \\
\hline Without grazing & 0.0189 & 37 \\
\hline One grazing & 0.0188 & 37 \\
\hline Two grazings & 0.0061 & 114 \\
\hline \multicolumn{3}{|c|}{ Remaining phosphorus } \\
\hline Without grazing & 0.0262 & 26 \\
\hline One grazing & 0.0276 & 25 \\
\hline Two grazings & 0.0093 & 75 \\
\hline \multicolumn{3}{|c|}{ Remaining potassium } \\
\hline Without grazing & 0.0564 & 12 \\
\hline One grazing & 0.0695 & 10 \\
\hline Two grazings & 0.0369 & 19 \\
\hline
\end{tabular}

(1) Decomposition constant; ${ }^{(2)}$ Half-life time. 

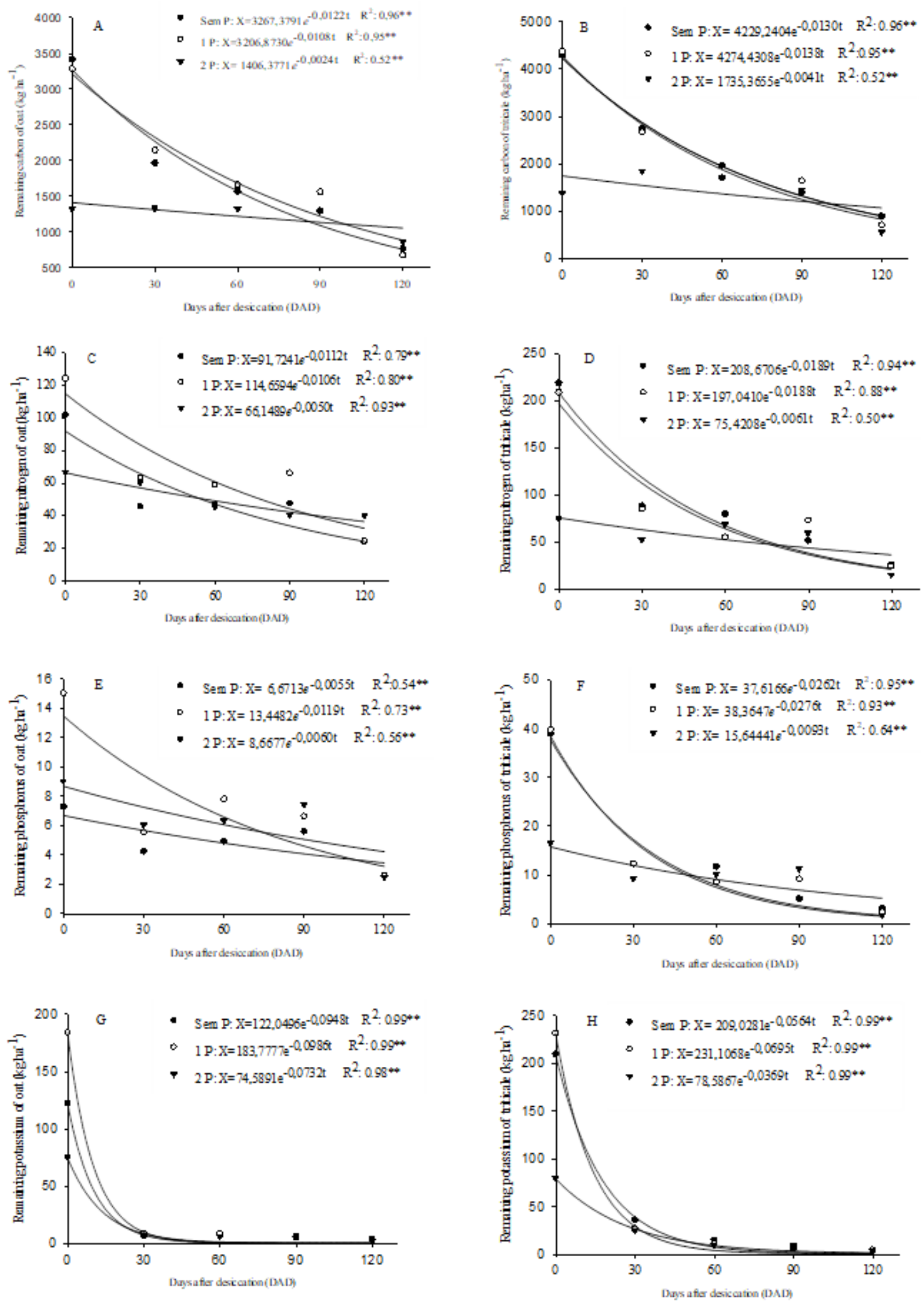

Figure 3. Remaining carbon, nitrogen, phosphorus, and potassium (kg ha-1) of the residues of white oat (cv. IPR Esmeralda) (A, C, E, G) and triticale (cv. IPR 111) (B, D, F, H) submitted to the managements without grazing (WG), one grazing (1G), and two grazings $(2 \mathrm{G})$, conducted in an integrated crop-livestock system. ** Significant at $1 \%$ by the $\mathrm{F}$ test, * Significant at $5 \%$ by the F-test. 
The first period evaluated for phosphorus in oats showed an amount of 7,15 , and $9 \mathrm{~kg} \mathrm{ha}^{-1}$ in areas without grazing, with one grazing and two grazings, respectively (Figure 3E). Piano et al. (2017), when evaluating the deposition and composition of the residual straw of IPR 126 oats in different densities and managements, found average values of 9,7 , and $5 \mathrm{~kg} \mathrm{ha}^{-1}$ of $\mathrm{P}$ for the areas without grazing, with one grazing and two grazings.

A reason for the nutrients to be present in greater concentration in the areas subjected to grazing can be attributed to the regrowth of the material, which provided an increase in the number of leaves, stems, and tillers with leaf expansion (Mattei et al., 2018), resulting in greater nutrient accumulation.

For triticale, phosphorus and nitrogen content had very similar behavior in areas not grazed and with only one grazing. The initial amounts present in the dry matter were $38 \mathrm{~kg} \mathrm{ha}^{-1}$ of $\mathrm{P}$, with approximately $92 \%$ available at 120 days after the management (Figure 3F). In the treatment subjected to two grazings, the initial levels were $16 \mathrm{~kg} \mathrm{ha}^{-1}$, releasing about $90 \%$ of the phosphorus present in the plant tissue at 120 DAM.

The half-life time for this nutrient in white oat crop was 26,25 , and 75 days for management without grazing, with one grazing and two grazings, respectively (Table 2). For triticale, the lowest $T^{1} / 2$ was observed in the area under grazing, which took, on average, 58 days to release $50 \%$ of the nutrient (Table 3 ). Similar results were obtained by Silva et al. (2014), who obtained $\mathrm{T} 1 \frac{1}{2}$ of 68 days for the same nutrient in black oat straw.

Most $\mathrm{P}$ of the plant tissue is found in the cell vacuole, quite soluble in water in the mineral form (Marschner, 1995). To $P$ be released from cultural residues, the vacuole must be broken. When considering that, during the first 30 days after crop management, the accumulated rain reached more than $150 \mathrm{~mm}$ (Figure 1), it is likely to think that during this period, most of the water-soluble $\mathrm{P}$ was leached from the crop residues of triticale. Then, the forms of $\mathrm{P}$ not soluble in water were left on the residues, thus dependent on the soil's microbial population for its mineralization (Giacomini et al., 2003).

According to Marcelo et al. (2012), the P released by crop residues to the soil will have little influence on crops in succession in a short period. This happens because low amounts of the element are released, being fixed to the soil's mineral particles. However, in the long term, there is the cumulative effect of P released annually by crops, contributing to compose an organic fraction of the nutrient in the soil and to the immobilization of $\mathrm{P}$ in microbial biomass.

Potassium, associated with the plant's structural components and the most abundant ion in plant cells (Taiz et al., 2017), was the nutrient with the greatest accumulation in plant tissue, both from oats and triticale. The average amounts accumulated in the remaining dry matter of the oats were $122 \mathrm{~kg} \mathrm{ha}^{-1}, 184 \mathrm{~kg} \mathrm{ha}^{-1}$, and 75 $\mathrm{kg} \mathrm{ha}^{-1}$; and for triticale of $209 \mathrm{~kg} \mathrm{ha}^{-1}, 197 \mathrm{~kg} \mathrm{ha}^{-1}$, and $75 \mathrm{~kg} \mathrm{ha}^{-1}$ for areas managed without grazing, with one grazing and two grazings, respectively (Figure $3 \mathrm{G}$ and $3 \mathrm{H})$.

When checking the availability of $\mathrm{K}$ from the oat vegetable residue under different sowing densities, Piano et al. (2017) obtained mean values of $67 \mathrm{~kg} \mathrm{ha}^{-1}, 55 \mathrm{~kg}$ $\mathrm{ha}^{-1}$ and $61 \mathrm{~kg} \mathrm{ha}^{-1}$ of potassium for the areas without grazing, one grazing, and two grazings, respectively, lower values than observed in this research. This discrepancy can be justified by the lower dry matter productivity observed in the studies, which obtained averages of $3.58 \mathrm{t} \mathrm{ha}^{-1}$ and $2.79 \mathrm{tha}^{-1}$ for 2014 and 2015 . Also, the nutrients were released faster by straw being mostly available up to 40 days. The estimated half-life for $\mathrm{K}$ was 12, 10, and 19 days for areas without grazing, with one and two grazings, respectively (Table 11).

The K release occurred very quickly because after 30 days, more than $90 \%$ and $70 \%$ of the nutrient contained in the remaining dry matter of oats and triticale, respectively, had already been made available to the soil (Figure $3 \mathrm{G}$ and $3 \mathrm{H}$ ). This can be explained by the fact that this nutrient is a constituent of non-structural components and frequently found in ionic form in plant cells' vacuole (Perin et al., 2010). Therefore, it can be easily washed by rainwater.

The rapid release of $\mathrm{K}$ from plant tissue becomes a favorable option for subsequent crops, which have a greater need for this element in the early stages of development, resulting in better use and reduction in mineral fertilizers.

\section{Conclusions}

After one or two grazings, the oat cultivar IPR Esmeralda and triticale cultivar IPR 111 can form enough straw to continue the no-tillage system.

The amount $\mathrm{N}, \mathrm{P}$, and $\mathrm{K}$ released from the remaining dry matter, regardless of the management adopted, decreased over time.

Potassium was the nutrient that showed the most accelerated release, with a half-life ranging from 7 to 19 days.

Triticale cultivar IPR 111, when grazed, is more efficient in nutrient cycling than IPR Esmeralda oats, providing 197, 38, and $231 \mathrm{~kg} \mathrm{ha}^{-1}$ of $\mathrm{N}, \mathrm{P}$, and $\mathrm{K}$, respectively.

The longest half-life time was obtained when two grazings were performed for all variables and regardless of the forage species used. 


\section{Acknowledgments}

This study was financed in part by the Coordenação de Aperfeiçoamento de Pessoal de Nível Superior - Brasil (CAPES) - Finance Code 001. We want to thank the Coordenação de Aperfeiçoamento de Pessoal de Nível Superior - Brasil (CAPES) for the scholarship and the resources to carry out the research and the National Council for Scientific and Technological Development (CNPq) for granting the productivity scholarship to the sixth author.

\section{Bibliographic References}

Acosta, J.A.A., Amado, T.J.C., Silva, L.S., Santi, A., Weber, M.A., 2014. Decomposição da fitomassa de plantas de cobertura e liberação de nitrogênio em função da quantidade de resíduos aportada ao solo sob sistema plantio direto. Ciência Rural, 44(5), 801-809. DOI: https://doi.org/10.1590/S010384782014005000002 .

Alvares, C.A., Stape, J.L., Sentelhas, P.C., Gonçalves, J.L.M., Sparovek, G., 2013. Köppen's climate classification map for Brazil. Meteorologische Zeitschrift, 22(6), 711-728. DOI: https://doi.org/10.1127/0941-2948/2013/0507.

Anghinoni, I., Assmann, J.M., Martins, A.P., Costa, S.E., Carvalho, P.C.F., 2011. Nutrient cycling in integrated croplivestock systems. Synergismus Scyentifica, 6(2), 1-8. DOI: https://doi.org/10.1007/978-1-4614-1587-9_7.

Assmann, A.L., Silva, H.L., Kirchner, R., Kozelinski, S.M., 2008. Espécies forrageiras para o sistema integração lavourapecuária. In: Assmann, A.L., Soares, A.B., Assmann, T.S., (Eds.). Integração lavoura-pecuária para a agricultura familiar. Londrina, IAPAR, p. 28-37.

Assmann, J.M., Anghinoni, I., Martins, A.P., Costa, S.E.V.G.D.A., Cecagno, D., Carlos, F.S., Carvalho, P.C.D.F., 2014. Soil carbon and nitrogen stocks and fractions in a longterm integrated crop-livestock system under no-tillage in southern Brazil. Agriculture Ecosystems Environment, 190(6), 52-59. DOI: https://doi.org/10.1016/j.agee.2013.12.003.

Braga, J.M., Defelipo, B.V., 1974. Determinação espectrofotométrica de fósforo em extratos de solo e material vegetal. Revista Ceres, 21(113), 73-85.

Calvo, C.L., Foloni, J.S.S., Brancalião, S.R., 2010. Phytomass yield and $\mathrm{C} / \mathrm{N}$ relation of single crops and intercrops of pegeon pea, sorghum and pear millet in three cut management times. Bragantia, 69(1), 77-86. DOI: https://doi.org/10.1590/S000687052010000100011.

CQFSRS/SC. Comissão de Química e Fertilidade do Solo, 2004. Manual de adubação e de calagem para os estados do Rio Grande do Sul e Santa Catarina. Porto Alegre, Sociedade Brasileira de Ciência do Solo - Núcleo Regional Sul.

Dubeux Jr., J.C.B., Sollenberger, L.E., Vendramini, J.M.B., Interrante, S.M., Lira Junior, M.A., 2014. Stocking method, animal behavior, and soil nutrient redistribution: how are they linked? Crop Science, 54(5), 2341-2350. DOI: https://doi.org/10.2135/cropsci2014.01.0076.
Dumbrava, M., Basa, A.G., Ion, V., Epure, L.I., Dinca, N., Stefan, D., 2014. Results regarding yield and yield components at different triticale varieties. Scientific Papers. Series A. Agronomy, 57, 174-179. https://doi.org/10.1016/j.aaspro.2016.09.023.

Ferreira, D.F., 2011. Sisvar: a computer statistical analysis system. Ciência e Agrotecnologia, 35(6), 1039-1042. DOI: https://doi.org/10.1590/S1413-70542011000600001.

Giacomini, S.J., Aita, C., Hubner, A.P., Lunkes, A., Guidini, E., Amaral, E.B., 2003. Phosphorus and potassium release during decomposition of crops residues in no-tillage system. Pesquisa Agropecuária Brasileira, 38(9), 1097-1104. DOI: https://doi.org/10.1590/S0100-204X2003000900011.

Hentz, P., Carvalho, N.L., Luz, L.V., Barcellos, A.L., 2014. Nitrogen cycling in crop-livestock systems. Ciência e Natura, 36(2), 663-676. DOI: https://doi.org/10.1590/S0100204X2015001000013.

Krutzmann, A., Cecato, U., Silva, A.P., Tormenta, C.A., Iwamoto, B.S., Martins, E.N., 2013. Palhadas de gramíneas tropicais e rendimento da soja no sistema de integração lavourapecuária. Bioscience Journal, 29(4), 842-851.

Marcelo, A.V., Corá, J.E., Fernandes, C., 2012. Crop sequences in no-tillage system: I - Dry matter production and nutrient accumulation. Revista Brasileira de Ciência do Solo, 36(5), 1568-1582. DOI: https://doi.org/10.1590/S010006832009000200019

Marschner, H., 1995. Functions of mineral nutrients: macronutrients, in: Marschner, H., (Ed.). Mineral nutrition of higher plants, second ed. San Diego, Academic, p. 229-312.

Mattei, E., Oliveira, P.S.R., Rampim, L., Egewarth, J.F., Rego, C.A.R.M., Piano, J.T., Herrera, J.L., 2018. Remaining straw and release of nutrients from oat managed in integrated croplivestock. Bioscience Journal, 34(1), 206-215. DOI: https://doi.org/10.14393/BJ-v34n6a2018-42036.

Medrado, R.D., Rios, E.M., Lopes, E.C.P., Carvalho, P.C.F., Moraes, A., Lang, C.R., 2011. Decomposition of the cultural residue and release nitrogen to culture of maize. Scientia Agraria, 12(2), 097-107.

Meinerz, G.R., Olivio, C.J., Fontaneli, R.S., Nornberg, J.L., Agnolin, C.A., Scheibler, R.B., Horst, T., Fontaneli, R.S., 2011. Valor nutritivo da forragem de genótipos de cereais de inverno de duplo propósito. Revista Brasileira de Zootecnia, 35(4), 1197-1206. DOI: https://doi.org/10.1590/S151635982011000600003 .

Moraes, A., Carvalho, P.C.F., Anghinoni, I., Lustosa, S.B.C., Costa, S.E.V.G.A., Kunrath, R.R., 2014. Integrated croplivestock systems in the Brazilian subtropic. European Journal of Agronomy, 57(7), 4-9. https://doi.org/10.1016/j.eja.2013.10.004.

Nicoloso, R.S., Lovato, T., Amado, T.J.C., Bayer, C., Lanzanova, M.E., 2008. Soil organic carbon budget under croplivestock integration in southern Brazil. Revista Brasileira de Ciência do Solo, 32(6), 2425-2433. DOI: https://doi.org/10.1590/S0100-06832008000600020.

Paul, E.A., Clark, F.E., 1989. Soil microbiology and biochemistry. San Diego, Academic Press. 
Perin, A., Santos, R.H.S., Caballero, S.S.S.U, Guerra, J.G.M., Gusmão, L.A., 2010. P, K, Ca and Mg accumulation and release by sunnhemp and millet in monocrop and intercropping. Revista Ceres, 57(2), 274-281. DOI: https://doi.org/10.1590/S0034-737X2010000200020.

Piano, J.T., Egewarth, J.F., Egewarth, V.A., Mattei, E., Bartzen, B.T., Oliveira, P.S.R., 2017. Deposition and composition of residual straw in area under integrated crop livestock. Revista Agrarian, 10(37), 234-243. DOI: https://doi.org/10.30612/agrarian.v10i37.6670.

Santos, H.G., Jacomine, P.K.T., Anjos, L.H.C., Oliveira, V.A., Lumbreras, J.F., Coelho, M.R., Almeida, J.A., Araujo Filho, J.C., Oliveira, J.B., Cunha, T.J.F., 2018. Sistema brasileiro de classificação de solos, quinta ed. rev. e ampl. Brasília, Embrapa.

Santos, F.C., Albuquerque Filho, M.R., Vilela, L., Ferreira, G.B., Carvalho, M.C.S., Viana, J.H.M., 2014. Decompostion and macronutrient release from maize and brachiaria straw under a crop-livestock system in the cerrado of Bahia. Revista Brasileira de Ciência do Solo, 38(6), 1855-1861. DOI: https://doi.org/10.1590/S0100-06832014000600020.

Silva, C.P., Monteiro, F.A., 2007. Nitrogen and calcium fertilization on tanzaniagrass morphogenesis and yield. Revista Brasileira de Zootecnia, 36(2), 335-342. DOI: https://doi.org/10.1590/S1516-35982007000200009.

Silva, D.J., Queiroz, A.C., 2006. Análise de alimentos: métodos químicos e biológicos, terceira ed. Viçosa, UFV.

Silva, M.P., Arf, O., Sá, M.E., Abrantes, F.L., Berti, L.F., Souza, L.C.D., Arruda, N., 2014. Straw and coverage levels of nutrients soil for plants coverage seeded in summer for direct seeding bean. Revista Agrarian, 7(24), 233-243.

Silva, P.R.F., Argenta, G., Sangoi, L., Strieder, M.L., Silva, A.A., 2006. Estratégias de manejo de coberturas de solo no inverno para cultivo do milho em sucessão no sistema de semeadura direta. Ciência Rural, 36(3), 1011-1020. DOI: https://doi.org/10.1590/S0103-84782006000300049.

Taffarel, L.E., Oliveira, P.S.R., Piano, J.T., Costa, P.B., Mesquita, E.E., Costa, P.F., Castagnara, D.D., Horn, M.B., Oliveira, E., 2017. Productivity and the presence of mycotoxins in oats, wheat, and triticale subjected to grazing. Semina: Ciências $\quad$ Agrárias, 38(6), 3749-3766. DOI: http://dx.doi.org/10.5433/1679-0359.2017v38n6p3749.

Taiz, L., Zeiger, E., Moller, I.M., Murphy, A., 2017. Plant Physiology and Development, sixth ed. Sinauer Associates, Sunderland.

Tedesco, M.J., Gianello, C., Bissani, C.A., Bohnen, H., Volkweiss, S.J., 1995. Análises de solo, plantas e outros materiais, second ed. UFRGS, Porto Alegre.

Thomas, R.J., Asakawa, N.M., 1993. Decomposition of leaf litter from tropical forage grasses and legumes. Soil Biology and Biochemistry, 25(10), 1351-1361. DOI: https://doi.org/10.1016/0038-0717(93)90050-L.

Wolschick, N.H., Barbosa, F.T., Bertol, I., Santos, K.F., Werner, R.S., Bagio, B., 2016. Canopy cover, biomass production and nutrient accumulation by coper crops. Revista de Ciências Agroveterinárias, 15(2), 134-143. DOI: https://doi.org/10.5965/223811711522016134. 